\title{
ANALISIS PENGAMBILAN KEPUTUSAN PEMBELIAN PETANI DALAM MEMILIH BENIH KELAPA SAWIT BERSERTIFIKAT DAN NON BERSERTIFIKAT DI KABUPATEN LABUHAN BATU UTARA
}

\author{
Laura Juita Pinem dan Safrida \\ Program Studi Agribisnis, Fakultas Agro Teknologi \\ Universitas Prima Indonesia \\ Email : laurajuita.pinem@gmail.com
}

\begin{abstract}
ABSTRAK
Penelitian ini bertujuan untuk mengidentifikasi karakteristik petani, menganalisis tahapan proses pengambilan keputusan pembelian petani dalam memilih benih bersertifikat dan non sertifikat, dan menganalisis faktor-faktor yang mempengaruhi proses pengambilan keputusan pembelian petani dalam memilih benih kelapa sawit bersertifikat dan non sertifikat di Kabupaten Labuhan Batu Utara. Penelitian ini dianalisis dengan bantuan 100 responden. Metode yang digunakan dalam penelitian ini adalah analisis deskriptif dan regresi logistik. Hasil dari analisis faktor membentuk 3 faktor yang mempengaruhi, yaitu faktor pendidikan, faktor ketahanan terhadap hama, dan penyakit dan faktor harga.
\end{abstract}

Kata kunci : pengambilan keputusan petani, benih sertifikat dan nonsertifikat, regresi logistic

The purpose of the study was to identify the characteristics of farmer, analyze farmer decision and factors that determine farmer decision to utilize certified and noncertified oil palm seed in Labuhan Batu Utara District, North Sumatera. This research use 100 farmer respondens. The method of the research is descriptive analysis and logistic regresion. The result showed that there were three major factors significantly influence the farmer's decision to use certified and noncertified oil palm seed in Labuhan Batu Utara District, there were education factor, resistance to pest and plant diseases factor, and price factor.

Keywords : farmer decision, certified and noncertified oil palm seed, logistic regresion

\section{A. PENDAhUluan}

Benih merupakan salah satu faktor penentu produksi tanaman selain dari dukungan faktor-faktor produksi lainnya seperti pupuk, air, cahaya, dan iklim. Benih yang bermutu rendah walaupun didukung oleh faktor-faktor produksi lainnya yang cukup maka hasilnya akan rendah karena mutu benih mencakup mutu genetis, mutu fisiologis, dan mutu fisik. Mutu genetis menunjukkan identitas genetis dari tanaman induknya sedangkan mutu fisiologis merupakan kemampuan daya hidup (viabilitas) benih yang mencakup daya kecambah dan kekuatan tumbuh benih. Sedangkan mutu fisik menunjukkan penampilan benih seperti ukuran homogen, bernas, bersih dari campuran, bebas hama dan penyakit, dan kemasan menarik.

Pembangunan pertanian harus didukung oleh pembangunan pembenihan karena faktor benih mempunyai kontribusi yang sangat tinggi dalam menentukan keberhasilan produksi dan produktifitas tanaman. Semakin tinggi mutu benih yang digunakan maka semakin besar produksi yang dihasilkan. Sertifikat benih merupakan salah satu bentuk pembangunan pembenihan. Sistem pengawasan mutu dan sertifikasi benih yang handal dapat melindungi keaslian varietas dan kemurnian genetik, baik yang diproduksi oleh produsen maupun yang digunakan oleh konsumen di lapangan agar sesuai dengan standar mutu benih yang berlaku. Benih yang bermutu tinggi diharapkan menjadi salah satu jaminan untuk meningkatkan produksi, produktivitas, dan mutu hasil pertanian yang berdaya saing, dan pada akhirnya bisa berdampak positif terhadap pendapatan dan kesejahteraan petani.

Kabupaten Labuhan Batu Utara merupakan salah satu kabupaten di Sumatera Utara yang menempatkan kelapa sawit sebagai salah satu komoditas unggulan. Banyak petani rakyat yang menggantungkan kehidupan mereka pada komoditas kelapa sawit. Ada sekitar 15.960 petani yang berkecimpung pada sektor ini. Tetapi produktifitas dari kelapa sawit yang dikelola oleh petani belum maksimal, hal ini ditunjukkan melalui data dari Direktorat Jenderal Perkebunan bahwa pada tahun 2016 Kabupaten Labuhan Batu Utara mempunyai luas area kelapa sawit sebesar 68.178 hektar dengan produktifitas $3.058 \mathrm{~kg} /$ ha sedangkan data dari lembaga yang sama menunjukkan bahwa di Sumatera Utara perkebunan yang dikelola oleh perkebunan swasta dan negeri bisa mencapai produktifitas $4.415 \mathrm{~kg} / \mathrm{ha}$. Salah satu alasan yang menjadi kemungkinan belum maksimalnya produktifitas kelapa sawit petani di Kabupaten Labuhan Batu Utara adalah karena penggunaan 
benih palsu atau benih yang tidak terjamin mutunya. Hal senada telah dianalisis Kariyasa (2015), dalam jurnalnya mengatakan bahwa petani yang menggunakan benih bersertifikat mampu mengembalikan modal yang diinvestasikan lebih cepat jika dibandingkan dengan petani yang menggunakan benih non sertifikat.

Banyaknya permintaan benih menyebabkan tidak terpenuhinya permintaan benih para petani kelapa sawit, hal ini merupakan salah satu peluang bagi produsen benih tidak resmi (palsu). Penggunaan benih palsu menimbulkan kerugian yang besar,karena produktifitas tanaman dari benih palsu kurang dari setengah tanaman dari benih unggul (litbang pertanian,2017). Beberapa produsen benih kelapa sawit legal yang ada di Indonesia adalah, Pusat penelitian Kelapa Sawit (PPKS) Medan, PT. Socfin Indonesia, PT.PP London Sumatera,Tbk, PT Binasawit Makmur (PT Sampoerna Agro, Tbk), PT. Tunggal Yunus Estate (Asian Agri Group), PT. Dami Mas Sejahtera (Smart Group), PT. ASDBakrie Oil Palm Seed Indonesia (Dijetbun, 2016).

\section{B. METODE PENELITIAN}

Data yang diperoleh dalam penelitian ini merupakan data primer yang didapat dengan menggunakan kuisioner dan wawancara terhadap responden. Sedangkan data sekunder dari penelitian ini didapat dari Badan Pusat Statistik, buku, internet, dan instasi lain yang terkait.

Jumlah sampel yang digunakan dalam penelitian ini adalah 100 responden. Jumlah sampel ini didapat dengan merujuk kepada Rumus Slovin yang digunakan untuk menentukan ukuran minimal sampel yang dibutuhkan dari suatu populasi sehingga mendapatkan sampel yang mewakili populasi.

Dimana:

$$
\mathbf{n}=\frac{N}{1+\epsilon^{2} N}
$$

$\mathrm{n}=$ Besar sampel

$\mathrm{N}=$ Besar populasi

tolerance) $10 \%$

$\epsilon=$ Batas toleransi kesalahan (error

Teknik pengolahan dan analisis data yang digunakan adalah metode deskriptif kualitatif dan Regresi Logistik. Metode pengumpulan data yang dipakai pada penelitian ini adalah teknik angket (kuisioner). Data diolah dengan menggunakan Microsoft Excel 2007 dan SPSS VERSI 22.

Analisis deskriptif bertujuan menyajikan data mentah yang didapat dalam penelitian menjadi lebih mudah untuk dipahami dengan membentuknya menjadi informasi yang ringkas. Faktor-faktor yang mempengaruhi pengambilan keputusan pembelian petani dalam memilih benih bersertifikat dan non sertifikat didapat dengan menggunakan pendekatan model regresi logistik atau logit. Pada model ini dideskripsikan hubungan antara peubah terikat yang memiliki dua kategori atau lebih dengan satu atau lebih peubah bebas berskala kategori atau interval.

Responden pada penelitian ini dikategorikan dalam kelompok petani pengguna benih bersertifikat dan kelompok petani pengguna benih non sertifikat. Faktor-faktor yang mempengaruhi keputusan pembelian petani dalam memilih benih diduga dipengaruhi oleh faktor pendidikan, pengaruh pihak lain, umur, pengalaman usaha tani, luas lahan, status kepemilikan lahan, persepsi, ketahanan benih terhadap hama dan penyakit tanaman, harga benih, dan akses benih. Variabel-variabel bebas $\mathrm{x}$ akan berpengaruh terhadap variabel terikat $Y$. Variabel terikat Y mempunyai dua kemungkinan nilai, yaitu 1 dan 0 . Nilai $Y=1$, berarti keputusan pembelian benih kelapa sawit bersertifikat sedangkan 0 berarti keputusan pembelian benih kelapa sawit non sertifikat. Model yang digunakan adalah sebagai berikut :

$$
\begin{gathered}
\mathrm{Yi}=\alpha+\beta 1 \mathrm{X} 1+\beta 2 \mathrm{D} 1+\beta 3 \mathrm{X} 2+\beta 4 \mathrm{X} 3+\beta 5 \mathrm{X} 4+ \\
\beta 6 \mathrm{D} 2+\beta 7 \mathrm{D} 3+\beta 8 \mathrm{D} 4+\beta 9 \mathrm{X} 5+\beta 10 \mathrm{D} 5
\end{gathered}
$$

Dimana :

Yi $\quad$ : Keputusan pembelian kelapa sawit

A : Intersep

X1 : Pendidikan (tahun)

D1 : Dummy pengaruh pihak lain (1=adanya pengaruh, 0 tidak ada pengaruh)

$\mathrm{X} 2 \quad$ : umur (tahun)

X3 : Pengalaman usahatani (tahun)

X4 : Luas Lahan (hektar)

D2 : Dummy status kepemilikan lahan ( $1=$ milik, $0=$ non milik $)$

D3 : Dummy persepsi (1= benih bersertifikat lebih baik darinon sertifikat, $0=$ benih bersertifikat tidak lebih baik dari benih non sertifikat)

D4 : Dummy ketahanan benih terhadap hama dan penyakit tanaman $(1=$ tahan, $2=$ tidak tahan $)$

X5 : Harga benih (Rp/kecambah)

D5 : Dummy akses benih ( $1=$ mudah, $0=$ sulit)

$\beta \mathrm{i} \quad$ : Parameter peubah Xi

e : error/kesalahan

\section{HASIL DAN PEMBAHASAN KARAKTERISTIK PETANI KELAPA SAWIT}

Karakteristik petani kelapa sawit diperlukan dalam penelitian ini untuk mengetahui sejumlah ciri atau sifat yang dimiliki oleh petani kelapa sawit dalam mengambil keputusan pembelian benih kelapa sawit serta faktor-faktor yang mempengaruhinya. Mengetahui karakterisktik dari petani merupakan salah satu informasi yang dibutuhkan produsen untuk menentukan segmentasi, target pasar dan positioning yang tepat (Kotler, 2016). Karakteristik responden yang digunakan dalam penelitian ini adalah usia, tingkat 


\section{ANALISIS PENGAMBILAN KEPUTUSAN PEMBELIAN PETANI}

pendidikan, lama berusaha tani, luas lahan, status kepemilikan.

Petani yang menggunakan benih bersertifikat didominasi oleh petani yang berada pada rentang usia 41-45 tahun. Menurut Bakir dan Maning (1984), umur produktif untuk bekerja di negara-negara maju pada umumnya adalah 15-55 tahun. Hal ini menunjukkan bahwa petani responden berada pada usia produktif sehingga petani pada usia ini masih memiliki keinginan untuk mengembangkan usahanya. Sedangkan petani yang menggunakan benih non sertifikat sebesar 52\% didominasi oleh petani yang berada pada rentang usia $>50$ tahun. Organisasi Kesehatan Dunia (WHO) menggolongkan lanjut usia menjadi
4 yaitu : usia pertengahan (middle age) 45 -59 tahun, lanjut usia (elderly) 60 -74 tahun, lanjut usia tua (old) 75 - 90 tahun dan usia sangat tua (very old) diatas 90 tahun. Bila berdasarkan data yang diberikan oleh WHO petani yang menggunakan benih non sertifikat merupakan petani yang berada pada jenjang lansia sehingga karakter yang melekat pada petani pada rentang usia ini adalah petani yang memiliki sifat yang sulit untuk dipengaruhi.

Berdasarkan tingkat pendidikan yang dienyam oleh petani yang menggunakan benih bersertifikat sekitar $44 \%$ menikmati pendidikan sampai level SMA sedangkan petani yang menggunakan benih non sertifikat berada

Tabel 1. Karakterisktik Responden Petani Benih Kelapa Sawit

\begin{tabular}{llllll}
\hline No & Karakteristik & \multicolumn{2}{c}{ Petani Benih Sertifikat } & \multicolumn{2}{c}{ Petani Benih Non Sertifikat } \\
\hline & & Kategori & $\begin{array}{l}\text { Persentase } \\
(\boldsymbol{\%})\end{array}$ & Kategori & $\begin{array}{l}\text { Persentase } \\
(\boldsymbol{\%})\end{array}$ \\
\hline 1 & Usia & $41-45$ & 38 & $>50$ & 52 \\
2 & Pendidikan & SMA & 44 & SD & 44 \\
3 & Luas Lahan & $0-5 \mathrm{Ha}$ & 76 & $0-5 \mathrm{Ha}$ & 90 \\
4 & Lama Berusaha Tani & $11-15$ Tahun & 42 & $16-25$ Tahun & 54 \\
5 & Status Kepemilikan & Milik Sendiri & 100 & Milik Sendiri & 100 \\
\hline
\end{tabular}

pada level pendidikan SD pada persentase yang sama. Tingkat pendidikan yang dimiliki petani mempunyai pengaruh terhadap pola pola pikir dan daya nalar seseorang, biasanya seseorang yang mengenyam pendidikan cukup lama akan lebih rasional dalam bertindak dan menjalankan usahanya (Afrizon, 2012).

Luas lahan merupakan salah satu faktor produksi penting dalam usahatani. Besar kecilnya lahan mempengaruhi besar kecilnya pendapatan tinggi.

baik sehingga produksi yang dicapai

Ditilik dari pengalaman dalam berusahatani, petani dengan benih sertifikat sekitar $42 \%$ sudah melakukan usahatani kelapa sawit selama 11-15 tahun sedangkan 54\% petani dengan benih nonsertifikat mengantungkan usahatani sebagai salah satu sumber penghasilnya selama 1625 tahun. Lamanya berusahatani merupakan yang diperoleh dari usahatani (Edwina, 2014). Data yang didapat dari petani dengan penggunaan benih sertifikat menunjukkan bahwa sebanyak $76 \%$ petani mempunyai lahan sekitar 2-5 Ha sedangkan pada petani yang menggunakan benih non sertifikat, persentase luas lahan dengan ukuran yang sama adalah 90\%. Berdasarkan luas lahan yang dimiliki oleh petani, petani mempunyai peluang untuk dapat berusahatani kelapa sawit dengan lebih pengalaman bagi petani yang mencerminkan kegiatan dan ketrampilan dalam mengelola usahataninya. Pengalaman cukup yang dimiliki petani akan melatih kemampuan dan kematangan petani dalam mempertimbangkan setiap langkah keputusan yang berkaitan dengan usahatani kelapa sawit yang sedang dijalankan. Hal ini sesuai dengan

Tabel 2. Tahap Pengenalan Kebutuhan Petani

\begin{tabular}{|c|c|c|c|c|c|}
\hline \multirow[t]{3}{*}{ No } & \multirow[t]{3}{*}{ Uraian } & \multicolumn{2}{|c|}{ Petani Benih Sertifikat } & \multicolumn{2}{|c|}{ Petani Benih Non Sertifikat } \\
\hline & & Jumlah & & Jumlah & \\
\hline & & $\begin{array}{c}\text { Responden } \\
\text { (Orang) }\end{array}$ & $\begin{array}{c}\text { Persentase } \\
(\%)\end{array}$ & $\begin{array}{c}\text { Responden } \\
\text { (orang) }\end{array}$ & $\begin{array}{c}\text { Persentase } \\
(\%)\end{array}$ \\
\hline \multirow[t]{4}{*}{1} & Motivasi menggunakan Benih & & & & \\
\hline & a. Harga terjangkau & - & - & 26 & 52 \\
\hline & b. Mudah diperoleh & 11 & 22 & 8 & 16 \\
\hline & c. Kualitas benih bagus & 39 & 78 & 16 & 32 \\
\hline
\end{tabular}


petani lain yang memberikan pengaruh dianggap lebih mempunyai pengalaman. Data dari tahap evaluasi alternatif dapat dilihat pada Tabel 4.

Selanjutnya petani akan membangun niat untuk memilih dan memutuskan untuk membeli benih yang akan dipilih untuk digunakan dalam usahataninya. Tahap ini dinamakan tahap keputusan pembelian. Data dari petani menunjukkan bahwa pada tahap ini petani lebih dominan merencanakan terlebih dahulu sebelum melakukan pembelian benih. Sebanyak $96 \%$ petani dengan benih sertifikat dan $78 \%$ petani dengan benih nonsertifikat melakukan perencanaan terlebih dahulu sebelum melakukan pembelian benih. Sedangkan yang paling berpengaruh dalam proses pembelian yang dilakukan oleh petani yang menggunakan benih sertifikat dengan benih nonsertifikat adalah diri sendiri dengan persentase masing-masing sebesar $82 \%$ dan $62 \%$. Dalam memilih sumber benih yang dipakai $33 \%$ petani memilih untuk membeli benih bersertifikat dari petani lain yang sudah berpengalaman sebelumnya. Sedangkan 54\% petani lebih memilih tengkulak benih sebagai sumber benih yang akan dipakai

Tabel 4. Evaluasi Alternatif Petani Pengguna Benih Bersertifikat dan Nonsertifikat

\begin{tabular}{|c|c|c|c|c|c|}
\hline \multirow[t]{2}{*}{ No } & \multirow[t]{2}{*}{ Uraian } & \multicolumn{2}{|c|}{ Petani Benih Sertifikat } & \multicolumn{2}{|c|}{ Petani Benih Non Sertifikat } \\
\hline & & $\begin{array}{l}\text { Jumlah } \\
\text { Responden } \\
\text { (Orang) }\end{array}$ & $\begin{array}{c}\text { Persentase } \\
(\%)\end{array}$ & $\begin{array}{l}\text { Jumlah } \\
\text { Responden } \\
\text { (orang) }\end{array}$ & $\begin{array}{c}\text { Persentase } \\
(\%)\end{array}$ \\
\hline \multirow[t]{6}{*}{1} & Informasi Penting & & & & \\
\hline & a. Kualitas & 34 & 68 & 14 & 28 \\
\hline & $\begin{array}{l}\text { b. Produktifitas } \\
\text { c. Ketahanan terhadap hama dan }\end{array}$ & 7 & 14 & 6 & 12 \\
\hline & penyakit & - & - & - & - \\
\hline & d. Harga benih & - & - & 21 & 42 \\
\hline & e.Ketersediaan benih & 9 & 18 & 9 & 18 \\
\hline \multirow[t]{4}{*}{2.} & Pertimbangan Memilih & & & & \\
\hline & a. Kebiasaan yang telah dilakukan & 8 & 16 & 18 & 36 \\
\hline & b. Mengikuti petani lain & 33 & 66 & 24 & 48 \\
\hline & c.Laku di pasaran & 9 & 18 & 8 & 16 \\
\hline
\end{tabular}

Tabel 5. Keputusan Pembelian Petani Benih Bersertifikat dan Nonsertifikat

\begin{tabular}{|c|c|c|c|c|c|}
\hline \multirow[t]{2}{*}{ No } & \multirow[t]{2}{*}{ Uraian } & \multicolumn{2}{|c|}{ Petani Benih Sertifikat } & \multicolumn{2}{|c|}{ Petani Benih Non Sertifikat } \\
\hline & & $\begin{array}{l}\text { Jumlah } \\
\text { Responden } \\
\text { (Orang) }\end{array}$ & $\begin{array}{c}\text { Persentase } \\
(\%)\end{array}$ & $\begin{array}{l}\text { Jumlah } \\
\text { Responden } \\
\text { (orang) }\end{array}$ & $\begin{array}{c}\text { Persentase } \\
(\%)\end{array}$ \\
\hline \multirow[t]{4}{*}{1} & Cara Pembelian Benih & & & & \\
\hline & a. Terencana & 48 & 96 & 39 & 78 \\
\hline & b. Tidak Terencana & - & - & 2 & 4 \\
\hline & c. Tergantung situasi & 2 & 4 & 9 & 18 \\
\hline \multirow[t]{5}{*}{2.} & Yang berpengaruh dalam proses pembelian & & & & \\
\hline & a. Diri Sendiri & 41 & 82 & 31 & 62 \\
\hline & b. Toko pertanian/pedagang benih & - & - & - & - \\
\hline & c. Petani/kelompok tani & 9 & 18 & 12 & 24 \\
\hline & d. Keluarga & - & - & 7 & 14 \\
\hline \multirow[t]{5}{*}{3} & Sumber Benih & & & & \\
\hline & a. Membuat sendiri & - & - & 4 & 8 \\
\hline & b. Membeli dari petani lain & 33 & 66 & 19 & 38 \\
\hline & c. Koperasi & 13 & 26 & - & - \\
\hline & d. Tengkulak benih & 4 & 8 & 27 & 54 \\
\hline \multirow[t]{2}{*}{4.} & Jarak Tempat Pembelian Benih & & & & \\
\hline & a. $1-5 \mathrm{~km}$ & 12 & 24 & 30 & 60 \\
\hline
\end{tabular}



b. $6-10 \mathrm{~km}$
18
36
7
14
c. $>10 \mathrm{~km}$
20
40
13
26

Tabel 6. Perilaku Pasca Pembelian Petani Benih Bersertifikat dan Nonsertifikat

\begin{tabular}{|c|c|c|c|c|c|}
\hline \multirow[t]{3}{*}{ No } & \multirow[t]{3}{*}{ Uraian } & \multicolumn{2}{|c|}{ Petani Benih Sertifikat } & \multicolumn{2}{|c|}{ Petani Benih Non Sertifikat } \\
\hline & & Jumlah & & Jumlah & \\
\hline & & $\begin{array}{c}\text { Responden } \\
\text { (Orang) }\end{array}$ & $\begin{array}{c}\text { Persentase } \\
(\%)\end{array}$ & $\begin{array}{l}\text { Responden } \\
\text { (orang) }\end{array}$ & $\begin{array}{l}\text { Persentase } \\
(\%)\end{array}$ \\
\hline \multirow[t]{4}{*}{1} & Kepuasan membeli benih & & & & \\
\hline & a. Puas & 50 & 100 & 9 & 18 \\
\hline & b. Biasa saja & - & - & 4 & 8 \\
\hline & c. Tidak puas & - & 4 & 37 & 74 \\
\hline \multirow[t]{3}{*}{2.} & Niat membeli kembali & & & & \\
\hline & a. Ya & 50 & 100 & 12 & 24 \\
\hline & b. Tidak & - & - & 38 & 76 \\
\hline \multirow[t]{3}{*}{3} & Jika Harga Benih Naik & & & & \\
\hline & a. Tetap membeli benih & 50 & 100 & 13 & 26 \\
\hline & b. Tidak membeli benih & - & - & 37 & 74 \\
\hline \multirow[t]{3}{*}{4.} & Varietas benihtidak tersedia & & & & \\
\hline & a. Mencari di tempat lain & 19 & 38 & 15 & 30 \\
\hline & b. Membeli varietas lain & 31 & 62 & 35 & 70 \\
\hline
\end{tabular}

5. benih
a. Ya
50
100
9
18
b. Tidak
- 41
82

berniat untuk membeli kembali benih yang pernah mereka pakai sementara $76 \%$ petani yang menggunakan benih nonsertifikat tidak berminat membeli kembali benih yang mereka pakai walaupun ada yang merasa puas dengan hasil benih. Hal ini disebabkan oleh pengaruh petani lain yang mengganggap bahwa produktifitas akan lebih tinggi bila menggunakan benih lain yang disarankan.

Harga merupakan salah satu faktor penentu keputusan petani dalam membeli benih. $100 \%$ petani dengan benih bersertifikat akan membeli benih yang sama kembali jika harga benih naik sementara $74 \%$ petani yang memilih benih nonsertifikat tidak berniat membeli kembali benih yang sudah mereka gunakan. Jika varietas benih yang dipakai tidak tersedia sebanyak $62 \%$ petani akan memilih benih bersertifikat dengan varietas lain sedangkan $70 \%$ petani akan memilih varietas lain dari benih nonsertifikat.

Kepuasan petani melihat hasil dari benih yang mereka pakai merupakan sarana promosi yang dapat diandalkan. Petani yang berpengalaman dalam memakai benih akan menjadi pemberi saran bagi petani pemula.100\% petani bersertifikat menyarankan orang lain untuk membeli benih yang dipakainya sementara $82 \%$ petani yang menggunakan benih lain dikarenakan petani tidak merasa puas dengan 
hasil yang didapat.

\section{FAKTOR-FAKTOR MEMPENGARUHI PETANI DALAM MEMILIH BENIH KELAPA SAWIT BERSERTIFIKAT DAN NONSERTIFIKAT}

Terdapat beberapa variabel yang merupakan faktor yang dapat mempengaruhi keputusan pembelianpetani kelapa sawit. Pada penelitian ini analisis regresi logistik akan digunakan untuk mengetahui faktor-faktor tersebut. Y merupakan variabel terikat pada analisis ini, variabel ini berupa kategorik, dimana petani kelapas awit yang memilih untuk membeli benih sertifikat diberi nilai 1 dan petani kelapa sawit yang memilih untuk membeli benih nonsertifikat diberi nilai 0. Berdasarkan literatur dan keadaan di lapangan maka dipilih 10 variabel bebas yang akan dianalisis. 10 variabel tersebut adalah pendidikan, pengaruh pihak lain, umur, pengalaman usahatani, luas lahan, status kepemilikan lahan,persepsi, ketahanan terhadap hama dan penyakit, harga benih, dan akses benih.

Nilai Nagelkerke $\mathrm{R}$ square digunakan sebagai parameter ketepatan model. Nilai Nagelkerke R square yang didapat adalah 0,863. Nilai ini menunjukkan bahwa keragaman variabel bebas dalam menjelaskan keragaman variabel terikat adalah sebesar 86,3 persen sedangkan sisanya sebesar 13,7 persen dijelaskan oleh variabel lain di luar model. Signifikansi dari model dalam memodelkan data diuji dengan uji Goodness-of-fit yang dilakukan dengan menggunakan metode Hosmer-Lemeshow (H-L). Uji dari model Tabel 7. Hasil Analisis Logistik untuk Faktor-Faktor yang Mempengaruhi Penggunaan Benih Bersertifikat dan Nonsertifikat

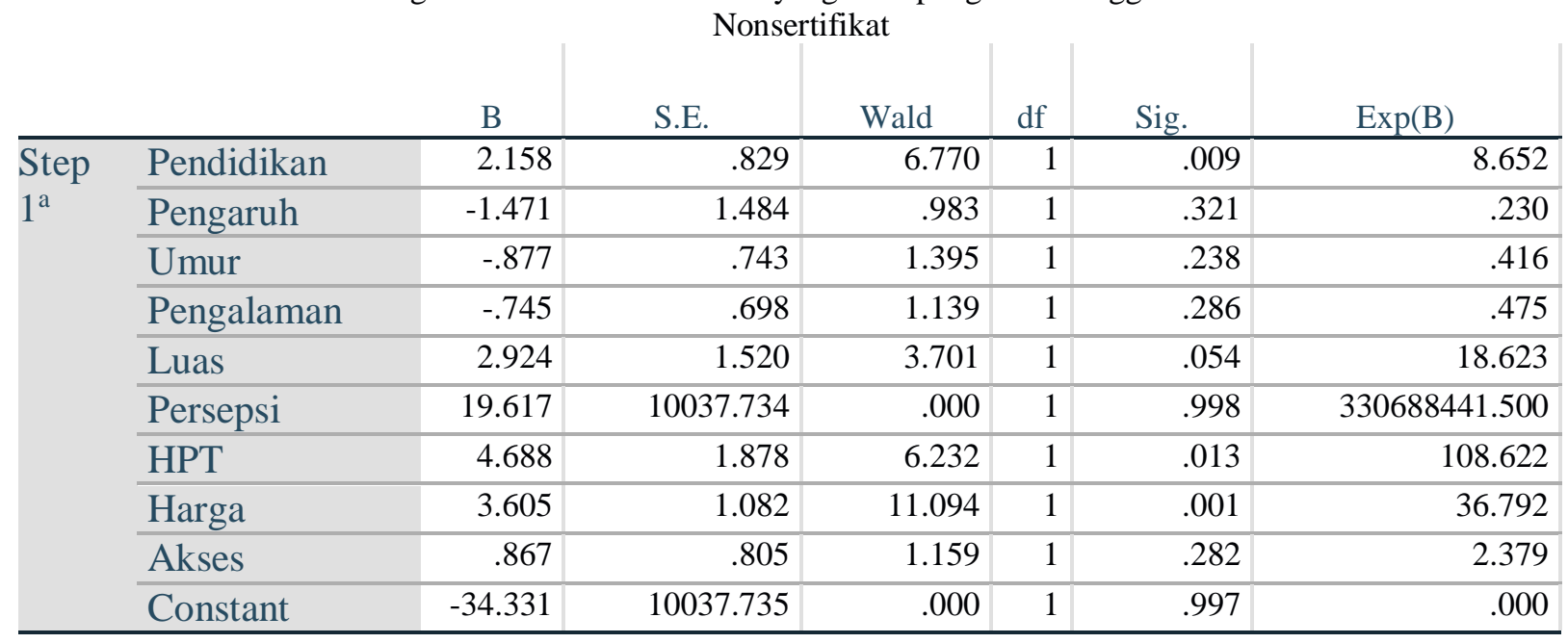

benih kelapa sawit sebesar 8.652 kali (cateris paribus).

Variabel ketahanan terhadap hama dan penyakit tanaman merupakan variabel selanjutnya yang mempunyai pengaruh yang signifikan terhadap keputusan petani dalam memilih benih menunjukkan hasil bahwa nilai statistik H-L test adalah 2.150 dan nilai $p$-value atau signifikansi yang dihasilkan adalah 0.976. Nilai $p$-value yang dihasilkan lebih besar dari taraf nyata 5 persen. Hasil tersebut menunjukkan bahwa model logit tersebut layak untuk digunakan karena secara keseluruhan mampu menjelaskan atau memprediksi keputusan petani dalam menggunakan benih kelapa sawit.

Pada tingkat kepercayaan 95 persen $(\alpha=$ $5 \%$ ), hasil dugaan model regresi menunjukkan bahwa terdapat tiga variabel yang memberikan pengaruh nyata terhadap keputusan petani memilih benih kelapa sawit, yaitu variabel pendidikan, variabel ketahanan benih terhadap hama dan penyakit tanaman serta variabel harga. Hasil pengolahan data dari regresi logistik dapat dilihat pada Tabel 7.

Variabel pendidikan memiliki nilai signifikansi sebesar 0,009 . Nilai ini menunjukkan bahwa variabel pendidikan mempengaruh signifikan terhadap keputusan petani dalam memilih benih kelapa sawit. Variabel ini memiliki koefisien positif, berarti peluang petani menggunakan benih bersertifikat berpengaruh positif dengan pendidikan, dengan kata lain semakin tinggi pendidikan maka kemungkinan petani menggunakan benih kelapa sawit bersertifikat semakin besar. Nilai odds ratio pada variabel pendidikan adalah 8.652, hal ini menunjukkan bahwa peningkatan pendidikan selama1 tahun akan meningkatkan keputusan penggunaan 
Nilai odds ratio pada variabel pendidikan adalah 108.622, hal ini menunjukkan bahwa semakin tinggi ketahanan benih terhadap hama dan penyakit akan meningkatkan keputusan penggunaan benih kelapa sawit sebesar 108.622 kali (cateris paribus)

Variabel harga benih memiliki nilai signifikansi sebesar 0.001 , sehingga variabel ini berpengaruh signifikan pada taraf $\alpha=5 \%$ terhadap keputusan pembelian petani dalam memilih benih kelapa sawit bersertifikat. Variabel ini memiliki koefisien positif, berarti peluang petani menggunakan benih bersertifikat berpengaruh positif dengan harga benih, dengan kata lain semakin tinggi harga benih maka kemungkinan petani menggunakan benih kelapa sawit bersertifikat semakin besar. Nilai odds ratio pada variabel pendidikan adalah 36.792, hal ini menunjukkan bahwa peningkatan harga sebesar Rp 1/kecambah akan meningkatkan keputusan penggunaan benih kelapa sawit sebesar 36.792 kali (cateris paribus). Schiffman dan Kanuk (2008), memaparkan bahwa harga merupakan salah satu dari beberapa faktor yang mempengaruhi konsumen. Melihat data harga merupakan salah satu jaminan yang digunakan oleh petani dalam memilih benih yang berkualitas. Berdasarkan penelitian yang dilakukan harga benih bersertifikat berkisar antara Rp 8.000 - Rp. 15.000 sementara harga benih nonsertifikat berada dikisaran harga Rp. 3.000 - Rp. 6.500. Jaminan kualitas dan produktifitas dari benih bersertifikat membuat petani tidak ragu untuk tetap menggunakan benih ini dan beranggapan bahwa kenaikan harga merupakan bentuk dari peningkatan kualitas benih.

\section{KESIMPULAN}

Pengambilan keputusan penggunaan benih kelapa sawit bersertifkikat dan nonsertifikat melalui lima tahapan,yaitu

pengenalan kebutuhan, pencarian informasi, evaluasi alternatif, keputusan pembelian, dan evaluasi pasca pembelian.

Perbedaan pengambilan keputusan antara

petani pengguna benih bersertifikat dan benih nonsertifikat adalah motivasi penggunaan benih. Petani memilih benih bersertifikat karena kualitas benih yang bagus sementara petani memilih menggunakan benih nonsertifikat karena harga benih yang terjangkau.

Faktor yang berpengaruh secara signifikan terhadap keputusan petani untuk menggunakan benih kelapa sawit bersertifikat dan nonsertifikat adalah pendidikan, ketahanan terhadap hama dan penyakit serta harga.

\section{DAFTAR PUSTAKA}

Emiria, F. dan H. Purwandari. 2014. Pengembangan pertanian organik di Kelompok Tani Madya, Desa Kebonagung, Kabupaten Bantul, Daerah Istimewa Yogyakarta. Jurnal Penyuluhan 10 (2).

Direktorat Jendral Perkebunan.2015. Statistik Perkebunan Indonesia. Jakarta. Kementerian Pertanian.

Engel, James F, R.D Blackweel, P.J. Winiard. 1995. Perilaku Konsumen, Jilid 1. Jakarta: Bina Rupa aksara.

Joni, M.M.A, M.F.R. Rubzen, and P.J.Batt. 2001. Factors influencing a farmer's decision to purchase seed potatoes in East Java. Paper presented at the 45th Annual Conference of the Australian Agricultural and Resource Economics Society, Adelaide, South Australia.

Kotler, P. dan Kevin Lane Keller. 2007. Manajemen Pemasaran Edisi 12. Jakarta: Indeks.

Kotler, P. dan Garry Amstrong. 2016. Principles of Marketing. Pearson Education. England.

Schiffman, and Kanuk. 2008. Perilaku KonsumenEd 7. Jakarta: PT. Indeks.

Sumarwan, U. 2004. Perilaku Konsumen: Teori Dan Penerapannya Dalam Pemasaran. Ghalia Indonesia. Bogor.

Sumarwan, U. 2010. Perilaku Konsumen. PT Ghalia Indonesia, Anggota IKAPI, Bogor.

Suryani, T. 2008. Perilaku Konsumen: Implikasi Pada Strategi Pemasaran. Graga Ilmu. Yogyakarta.

Umar. H. 2000. Riset Pemasaran dan Perilaku Konsumen. Gramedia Pustaka Utama. Jakarta.

Umar, H. 2005. Riset Pemasaran dan Perilaku Konsumen. PT Gramedia Pustaka Umum. Anggota IKAPI. Jakarta 